\title{
Entrevista
}

\section{Michael Löwy - 80 anos de Sete ensaios de interpretação da realidade peruana, de Juan C. Mariátegui}

Leandro Galastri ${ }^{1}$

No momento em que se completam 80 anos da primeira edição de "Sete ensaios de interpretação da realidade peruana", os Cadernos Cemarx não poderiam deixar de registrar o aniversário desta que figura entre as maiores obras do marxismo latino-americano. Entrevistamos Michel Löwy, conhecido intelectual brasileiro radicado na França e pesquisador do CNRS (Centre National de la Recherche Scientifique) de Paris, especialista, entre outros temas do pensamento socialista, também em José Carlos Mariátegui. Sobre o assunto, é organizador de importante coletânea em português do Amauta lançada em 2005 pela editora da Universidade Federal do Rio de Janeiro (Por um socialismo indo-americano, ed. UFRJ, 2005) e autor de textos em que analisa o que considera ser o romantismo revolucionário de Mariátegui, como "Marxismo y religión: opio del pueblo?" (La teoría marxista hoy, organização de Atílio Borón et al., Buenos Aires, ed. CLACSO, 2006) e "Mística revolucionária: José Carlos Mariátegui e a religião" (Estudos Avançados 19 (55), USP, 2005). Na entrevista que se segue, fica demonstrada pelo prof. Löwy a necessidade de expansão dos estudos e pesquisas sobre Mariátegui no Brasil em função da rica contribuição que o marxista peruano ainda tem por fornecer às ciências sociais de língua portuguesa e, por que não, ao fortalecimento da militância socialista em nosso país.

$* * * * *$

1 Doutorando em Ciência Política pelo IFCH/Unicamp. Agradeço a Danilo Martuscelli pela sugestão de realização desta entrevista, ao lembrar da data em questão.

cadernos cemarx, $\mathrm{n}^{\mathrm{0}} 5-2009 \quad 227$ 
Cadernos Cemarx - Como o senhor avalia a presença do pensamento de Mariátegui no marxismo latino-americano atual?

Michael Löwy - É interessante constatar que os latino-americanos voltam a descobrir o pensamento de Mariategui no momento em que começa a discussão em torno de um "socialismo do século 21". Não é só Hugo Chavez que menciona com freqüência o Amauta peruano como um de seus inspiradores, mas vários grupos de jovens revolucionários venezuelanos se referem ao marxismo libertário de Mariátegui. $\mathrm{Na}$ Argentina, se observa, no curso dos últimos anos, a multiplicação de trabalhos de pesquisa de alto nível - como por exemplo os de Horacio Tarcus e Nestor Kohan sobre a obra de Mariátegui e sua relação com a história do socialismo e das lutas sociais neste país. Sem falar, naturalmente, do Peru, onde as idéias do autor dos Sete ensaios nunca deixaram de estar presentes na cultura e na vida política da esquerda. Quanto mais a América Latina se deslocar à esquerda, isto é, em ruptura com o imperialismo e com o próprio sistema capitalista, quanto mais se colocar na ordem do dia o socialismo como única alternativa ao "Consenso de Washington", tanto mais se estudará e discutirá do pensamento do Amauta.

Cadernos Cemarx - O senhor é um dos raros intelectuais brasileiros que já se ocuparam com a difusão em língua portuguesa da obra do marxista peruano, que continua escassa em nosso idioma. Os marxistas brasileiros estudam pouco Mariátegui?

Michael Löwy - Infelizmente Mariátegui ainda continua pouco conhecido no Brasil. Claro, houve exceções, como Florestan Fernandes, que o considerava como "um dos clássicos do pensamento marxista e latino-americano", e que prefaciou a edição brasileira dos Sete ensaios (1975). Em 1982, aparece uma seleção de seus textos, preparada por Manuel Belotto e Ana Maria Martinez, na coleção "Grandes Cientistas Sociais" (dirigida por Florestan Fernandes) e, em 1983, um pequeno volume apresentando Mariátegui na coleção "Encanto Radical" da Editora Brasiliense, de autoria de um argentino radicado no Brasil, Hector Alimonda. Mais recentemente, foram publicadas duas antologias, uma pela Editora Boitempo, organizada por Luiz Bernardo Pericás, e outra, organizada por mim, pela Editora da Universidade Federal do Rio de Janeiro. Pouco depois (2006), a Editora "Expressão Popular" publicou a tese de doutorado de Leila Escorsim, Mariátegui, Vida e Obra. Embora eu discorde de algumas das interpretações desta autora - creio que se engana ao tentar dissociar

\begin{tabular}{l|l}
\hline 228 & Entrevista - Michael Löwy
\end{tabular} 
o marxismo do Amauta de sua dimensão romântico-revolucionária - acho muito importante que este livro esteja sendo difundido por uma editora próxima ao MST, permitindo assim que um grande número de seus quadros e militantes descubram as idéias do marxista peruano, e tenham vontade de ler seus escritos. ${ }^{2}$

Cadernos Cemarx - Passados quase 80 anos da publicação dos Sete ensaios de interpretação da realidade peruana, principal obra de Mariátegui, o que há nela de aportes ainda válidos para a abordagem crítica das sociedades latino-americanas contemporâneas de maioria indígena?

Michael Löwy - Os Sete ensaios são um exemplo notável de análise marxista de uma realidade sócio-histórica, em seus aspectos econômicos, sociais, políticos, religiosos, culturais, literários. A idéia mais importante do livro, que é de grande atualidade em boa parte da America Latina, indígena ou indo-americana mestiça, é a sugestão de que as comunidades indígenas tradicionais - no Peru, de origem inca são "a expressão empírica de um espirito comunista". Suas práticas de cooperação, solidariedade e coletivismo podem ser o ponto de partida de sua adesão ao projeto socialista moderno, em aliança com a classe trabalhadora das cidades. Como pensar um projeto socialista hoje, não só no Peru e na Bolívia, mas também no Equador, na Guatemala e no México - e, de certa maneira, em todo o continente - sem tomar em conta estas raízes indígenas de uma alternativa comunitária radical ao capitalismo?

Mas seria um equívoco considerar Mariátegui como o autor de um só livro e isolar os Sete ensaios do resto de sua obra; é o conjunto de seus escritos, seus ensaios filosóficos, literários, políticos, comparáveis, pela sua originalidade, à dos grandes marxistas heterodoxos europeus dos anos 1920, Gramsci, Lukacs, Walter Benjamin, que merece ser redescoberta.

Cadernos Cemarx - Que tipo de contribuição Mariátegui ainda seria capaz de fornecer à organização da prática revolucionária na América Latina?

Michael Löwy - Em 1928, para o segundo aniversário de sua revista Amauta, José Carlos Mariátegui escreveu um editorial, intitulado "Aniversário e Balanço"; este curto texto, de apenas 3 ou 4 páginas, contém algumas das idéias mais importantes do pensador marxista peruano. Hoje, oitenta anos mais tarde, estas idéias são de uma incrível atualidade, e apontam para aspectos fundamentais de uma prática

2 À época da entrevista (janeiro de 2008) ainda não existia a nova edição em português recém-lançada (julho último) pela editora Expressão Popular em conjunto com o Clacso (Conselho Latino Americano de Ciências Sociais), iniciativa dos editores também em homenagem aos 80 anos do aparecimento de "Sete ensaios".

cadernos cemarx, $\mathrm{n}^{\mathrm{0}} 5-2009 \quad 229$ 
revolucionária latino-americana. Gostaria de destacar duas teses deste histórico documento:

I. “À América do Norte capitalista, plutocrática, imperialista, só é possível opor eficazmente uma América, latina ou ibérica, socialista. A época da livre concorrência na economia capitalista terminou em todos os campos e sob todos os aspectos. Estamos na época dos monopólios, vale dizer dos impérios. Os países latinoamericanos chegaram com atraso à concorrência capitalista. Os primeiros postos já estão definitivamente ocupados. O destino destes países, dentro da ordem capitalista, é o de simples colônias".

Poderia se substituir "semi-colônias" em vez de colônias, mas os termos do debate são exatamente estes, em 2008. Assistimos na verdade, sob a égide do neoliberalismo e do "Consenso de Washington", à uma sorte de neo-colonização do continente, em que suas economias são mais uma vez relegadas à produção de matérias primas e produtos agrícolas para o mercado mundial. O caso do Brasil atual, com o espetacular desenvolvimento da cana de açúcar, visando agora não mais a alimentação, mas os tanques de gasolina dos carros nos Estados Unidos, é uma espetacular ilustração deste processo.

O debate sobre o socialismo do século 21 na América Latina atual está baseado precisamente na tese de Mariátegui: só por este caminho poderemos por um fim à dominação imperialista do continente.

II. "O socialismo, afinal, está na tradição americana. A mais avançada organização comunista primitiva que a historia registra, é a inca.

Não queremos, certamente, que o socialismo seja na América decalque e cópia. Deve ser criação heróica. Temos de dar vida, com nossa própria realidade, na nossa própria linguagem, ao socialismo indo-americano. Eis uma missão digna de uma geração nova".

Durante muito tempo a maioria dos marxistas na América Latina só conhecia o "decalque e cópia", em particular da experiência soviética. Um dos temas centrais da discussão sobre o socialismo do século 21, não só na Venezuela, mas em todo o continente, é a busca de novas alternativas, de novos projetos socialistas, apoiados em "nossa própria realidade", evitando os erros do passado, os impasses, tanto da socialdemocracia européia, que acabou pactuando com o capitalismo e com o colonialismo, quanto do estalinismo, esta triste caricatura burocrática do socialismo.

Está na ordem do dia a "criação heróica" de um grande projeto revolucionário,

\begin{tabular}{l|l}
\hline 230 & Entrevista - Michael Löwy
\end{tabular} 
um socialismo indo-afro-americano, mas isto não se dará sem uma longa e difícil série de enfrentamentos com as oligarquias capitalistas e imperiais, cujo desfecho ainda é imprevisível... 